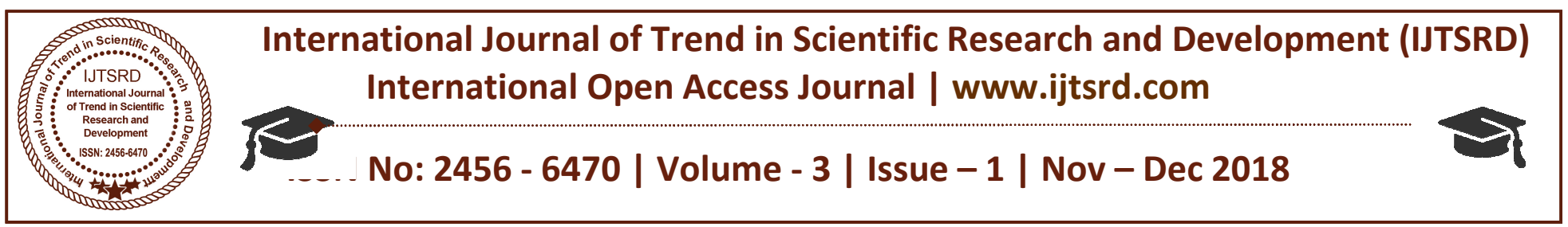

\title{
Mobility and Distribution of Some Selected Trace Metals in Soil from Dumpsite in Lafia, Nasarawa State
}

\author{
Gube-Ibrahim Mercy Ayinya \\ Department of Chemistry, College of Education \\ Akwanga, Nasarawa State, Nigeria
}

\author{
Ibrahim Ezekiel Gube \\ Department of Chemistry, University of Jos, \\ Plateau State, Nigeria
}

\begin{abstract}
Mobility and distribution of some selected trace metal was carried out using Tessier et al 1979sequential extraction method and the results obtained shows from dumpsite $\mathrm{A}$, samples taken from $0-5 \mathrm{~cm}$ the result ranges from $0.56-21.56 \%, 0.34-40.66 \%$, $1.34-29.18 \%, 0.06$ to $45.91 \%$ and $0.37-12.95 \%$ for the exchangeable, $\mathrm{Fe}-\mathrm{Mn}$ oxide, organic carbonate and residual fractions respectively. For the samples taken from $10-15 \mathrm{~cm}$ at dumpsite $\mathrm{A}$, the results of the fractions are $0.42-13.63 \%, 0.03-18.48 \%, 1.01-$ $25.34 \%, 0.03-35.19 \%$ and $0.27-9.31 \%$ for exchangeable, $\mathrm{Fe}-\mathrm{Mn}$ oxide, organic, carbonate and residual fractions. The results of dumpsite Bare 0.48$27.36 \%, 0.28-40.07 \%, 2.93-31.15 \%, 3.87-42.50 \%$ and $0.84-30.67 \%$ for exchangeable, Fe-Mn oxide, Organic, carbonate and residual fractions for sample taken from $0-5 \mathrm{~cm}$ while for samples taken from $10-$ $15 \mathrm{~cm}$ the results show $0.32-36.38 \%, 0.23-16.49 \%$, $0.53-15.83 \%, 1.53-34.88 \%$ and $0.04-5.27 \%$ for exchangeable $\mathrm{Fe}-\mathrm{Mn}$ oxide, carbonate and residual fractions respectively. The dumpsite $\mathrm{C}$ has the concentration of the various fractions ranging from $0.25-18.34 \%, 2.73$ to $15.58,4.02-23.28 \%, 0.07-$ $45.25 \%$ and $1.57-37.43 \%$ for exchangeable, $\mathrm{Fe}-\mathrm{Mn}$ oxide, organic, carbonate and residual for samples taken from $0-5 \mathrm{~cm}$ while for samples taken between $10-15 \mathrm{~cm}$ the concentrations are $0.42-12.62 \% 0.80$ $-11.59 \%, 2.16-17.33 \%, 9.86-34.48 \%$ and $0.99-$ $32.99 \%$ respectively.
\end{abstract}

KEY WORDS: Heavy metals, Mobility, Distribution, Toxicity and Speciation

\section{INTRODUCTION}

Over centuries, anthropogenic activities such as mining metallurgical processes, burning of fossil fuels, industrial production and agricultural operations have resulted in extensive heavy metal contamination which threatens the well-being of the global environment of today. Contamination of heavy metals in the environment has attracted global attention owing to its abundance, persistence and environmental toxicity. Both natural and anthropogenic activities are responsible for the abundance of heavy metals in the environment (Sanchez et al, 2007).

Heavy metals are considerably dangerous due to their toxicity, wide sources, lack of biodegradable properties and accumulative behaviour (mansouri et al, 2012 and Salati et al, 2010). These heavy metals have the ability to enter the human body through inhalation, ingestion and dermal contact absorption (Adelekan, et al, 2011). The toxicity of these metals is a major environmental concern and potentially dangerous because of bioaccumulation.Through the food chain; they tend to accumulate in the soil, water, sediment and organisms because they are not easily degradable. These toxic metals get to human through food chain.

High concentration of these metals causes wide range of diseases in human such as abdominal pain, hypertension, cardiovascular diseases, immune dysfunction, liver disease, anorexia and kidney related disorders as well as various kinds of cancers due to excessive intake in contaminated food and drinking water. For instance, heavy metals such as lead $(\mathrm{Pb})$, Cadmium (Cd) and Arsenic (As) etc are toxic and most especially lead can adversely influence the intelligence development of children, cause excessive lead in the blood, induce hypertension, nephropathy and cardiovascular disease. Research have shown that soil contamination by heavy metals is a serious 
environmental problem with significant implication for human health (Yashim, Agbaji, Gimba and Idris, 2016).

These heavy metals are characterized by their toxicity. The complexity of chemical speciation of these metals gives information about their bioavailability, mobility and toxicity which total metal determination alone could not provide the information leading to their availability and mobility.

Dumpsite is where waste materials are disposed and is the oldest form of waste management (Ibrahim et al, 2013).Historically dumpsites have been the most popular method of un-organized waste disposal and remain so in many places around the world. Most dumpsites are located within the vicinity of living communities and wetlands.

This study seeks to determines the mobility and availability of selected trace metals in soil samples from the selected dumpsites.

\section{Materials and Method}

All the chemicals and reagents used were of analytical grade (AR) and double distilled water was used throughout the research work.

\section{Study Area}

Three dumpsites in Lafia were selected for the research work, because they are the major dumpsites where all the waste in the city are deposited, this involve disposal of metal containing materials. Lafia is the capital of Nasarawa State in middle belt of Nigeria,with the population of 330,712 in habitats according to the 2006 census. The city lies at the latitude $8^{0} 29{ }^{\prime} 38.04^{\prime \prime} \mathrm{N}$ and longitude $8^{0} 55.11^{\prime \prime} \mathrm{E}$.

\section{Sample Collection and Treatment}

Soil samples from the three dumpsite were collected using stainless steel scoop into a polyethylene bags previously soaked with dilute nitric acid for $24 \mathrm{hrs}$, rinsed with distilled water and dried. The samples were collected in three different locations of each of the dumpsite and mixed thoroughly to obtain a representative sample at the depth of $0-5 \mathrm{~cm}$ and $10-$ $15 \mathrm{~cm}$. These samples were then transported to postgraduate chemistry laboratory and air dried for two weeks at room temperature and grinded with mortar and pestle. The grinded soil sample was sieved using $0.2 \mathrm{~mm}$ sieve size and bottled in a polyethylene bottles for further treatment.

For the total metal determination, one gram of each of the dried sieve soil from each dumpsite was digested with a mixture of $15 \mathrm{ml}$ hydrochloric acid (concentrated) and $25 \mathrm{ml}$ nitric acid for $2 \mathrm{hrs}$ at $100^{\circ} \mathrm{C}$ after cooling the mixture was filtered and made up to $50 \mathrm{ml}$ with double distilled water and the concentration of these metals were quantified in triplicate which the mean and the standard deviation was computed. The quantification was done using AAS model 7000 series East and West Analytical instrument, after running series of standards to obtained a calibration curve which was used for the quantification of the metals.

For the speciation analysis Tessier et al 1979 method was used as described below.

1. Exchangeable. Each of the three sieved soil samples $1.00 \mathrm{~g}$ each was extracted using $20 \mathrm{ml}$ of $1 \mathrm{~m} \mathrm{MgCl}_{2}$ in an orbit mechanized shaker for one hour at a $\mathrm{pH}$ of 7 , after which the mixture was filtered and the filtrate was analyzed for the selected metals using AAS model 7000 series East and West Analytical instrument.

2. Carbonate fraction: - The residue from fraction 1 was shaken with $20 \mathrm{ml} 1 \mathrm{~m} \mathrm{CH}_{3} \mathrm{COONa}$ at room temperature for five hours at the $\mathrm{pH}$ of 5 . The filtrate was analyzed by AAS model 7000.

3. $=\mathrm{Fe}-\mathrm{Mn} / \mathrm{Reducible}$ fraction: The residue from the fraction 2 was extracted with $10 \mathrm{ml} 0.04 \mathrm{~m}$ $\mathrm{NH}_{2} \mathrm{OH} . \mathrm{HCl}$ and $10 \mathrm{ml}$ of $25 \% \mathrm{CH}_{3} \mathrm{COOH}$ at $96^{\circ} \mathrm{C}$ for $6 \mathrm{hrs}$. The filtrate was analyzed with AAS 7000 .

4. 3.Organic Fraction: - The residue from fraction 3 was extracted with $9 \mathrm{ml}$ of $0.02 \mathrm{~m} \mathrm{HNO}_{3}$ and $15 \mathrm{ml}$ of $\mathrm{H}_{2} \mathrm{O}_{2}$ at $85^{\circ} \mathrm{C}$ on a water bath for $5 \mathrm{hrs}$ after $2 \mathrm{hrs}$ another $15 \mathrm{ml}$ of $30 \% \mathrm{H}_{2} \mathrm{O}_{2}$ was added.

5. Residual Fraction: The residue from fraction 4 was extracted using aqua regia $(7.5 \mathrm{ml}$ of $37 \% \mathrm{HCl}$ and $2.5 \mathrm{ml}$ of $65 \% \mathrm{HNO}_{3}$ at $85^{\circ} \mathrm{C}$ (Maina et al, 2012). The concentrations of the heavy metals were determined by Atomic absorption spectrometry (AAS) model 7000 East and West Analytical instrument. 
International Journal of Trend in Scientific Research and Development (IJTSRD) ISSN: 2456-6470

\section{Results and Discussion}

Table 1: Total metal concentration $\left(\mathrm{mgkg}^{-1}\right)$

\begin{tabular}{|c|c|c|c|c|c|c|c|}
\hline Sample & $\mathrm{Pb}$ & $\mathrm{Cu}$ & $\mathrm{Zn}$ & $\mathrm{Fe}$ & $\mathrm{Mn}$ & $\mathrm{Cd}$ & $\mathrm{Cr}$ \\
\hline $\begin{array}{c}\text { Dumpsite } \\
\text { A }\end{array}$ & $\begin{array}{c}1.306 \pm \\
0.05\end{array}$ & $\begin{array}{c}0.071 \pm \\
0.01\end{array}$ & $\begin{array}{c}0.950 \pm \\
0.05\end{array}$ & $\begin{array}{c}0.730 \pm \\
0.05\end{array}$ & $\begin{array}{c}0.100 \pm \\
0.01\end{array}$ & $\begin{array}{c}0.25 \pm \\
.0 .10\end{array}$ & $\begin{array}{c}0.370 \pm \\
0.02\end{array}$ \\
\hline $\begin{array}{c}\text { Dumpsite } \\
\text { B }\end{array}$ & $\begin{array}{c}1.501 \pm \\
0.20\end{array}$ & $\begin{array}{c}0.140 \pm \\
0.01\end{array}$ & $\begin{array}{c}3.20 \pm \\
0.70\end{array}$ & $\begin{array}{c}0.43 \pm \\
0.02\end{array}$ & $\begin{array}{c}6.680 \pm \\
0.30\end{array}$ & $\begin{array}{c}0.430 \pm \\
0.02\end{array}$ & $\begin{array}{c}0.460 \pm \\
0.04\end{array}$ \\
\hline$\underset{\text { C }}{\text { Dumpsite }}$ & $\begin{array}{c}0.650 \pm \\
0.03\end{array}$ & $\begin{array}{c}0.214 \pm \\
0.02\end{array}$ & $\begin{array}{c}3.850 \pm \\
0.40\end{array}$ & $\begin{array}{c}0.320 \pm \\
0.01\end{array}$ & $\begin{array}{c}0.320 \pm \\
0.02\end{array}$ & ND & $\begin{array}{c}0.400 \pm \\
0.03\end{array}$ \\
\hline $\begin{array}{c}\text { Dumpsite } \\
\mathrm{A}_{12}\end{array}$ & ND & ND & ND & ND & $\begin{array}{c}0.370 \pm \\
0.02\end{array}$ & $\begin{array}{c}0.100 \pm \\
0.01\end{array}$ & $\begin{array}{c}0.430 \pm \\
0.02\end{array}$ \\
\hline $\begin{array}{c}\text { Dumpsite } \\
\mathrm{B}_{12} \\
\end{array}$ & ND & ND & ND & ND & ND & $\begin{array}{c}0.22 \pm \\
0.01\end{array}$ & $\begin{array}{c}0.120 \pm \\
0.01\end{array}$ \\
\hline
\end{tabular}

ND $=$ Not Detected

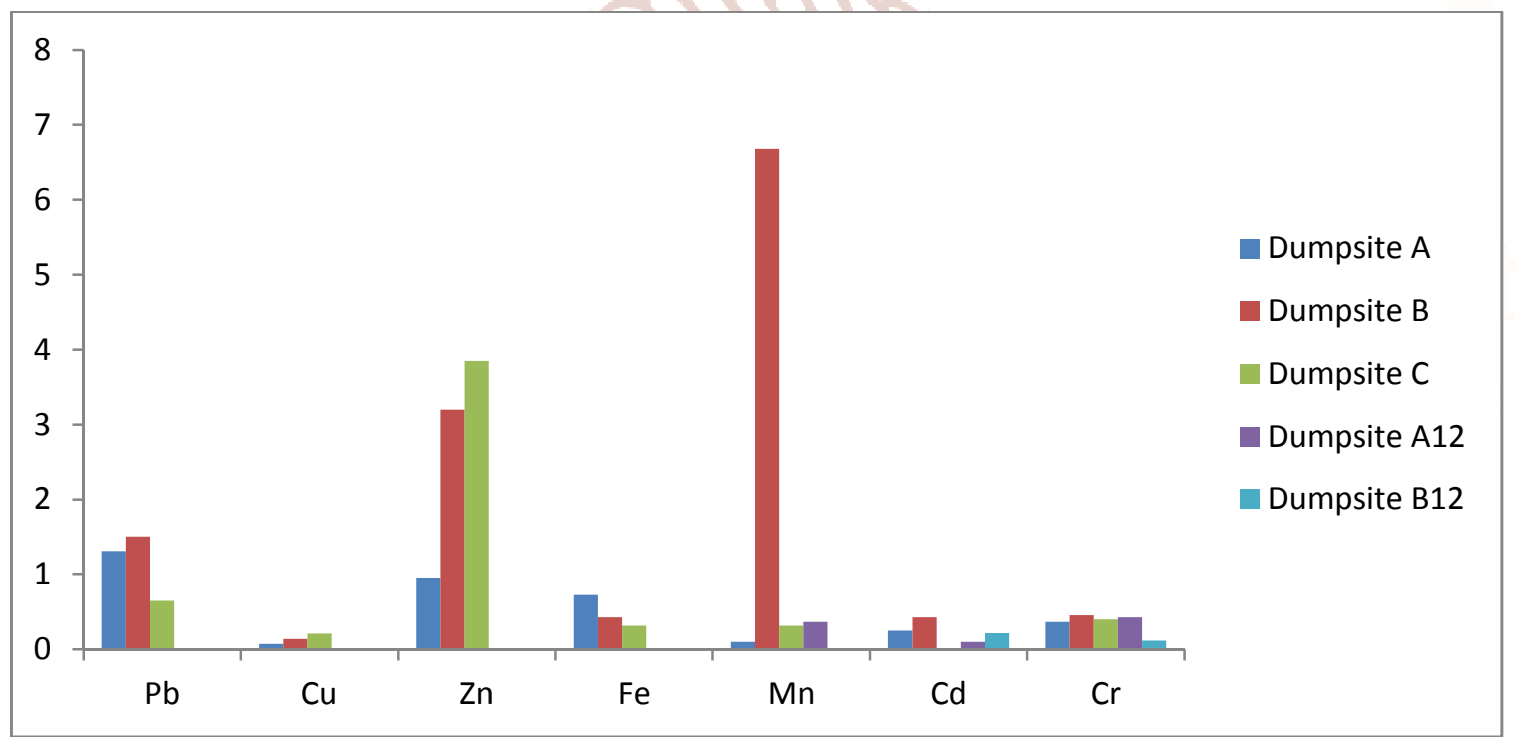

Figure 1 Concentration of total metals in various Dumpsites (mg/kg)

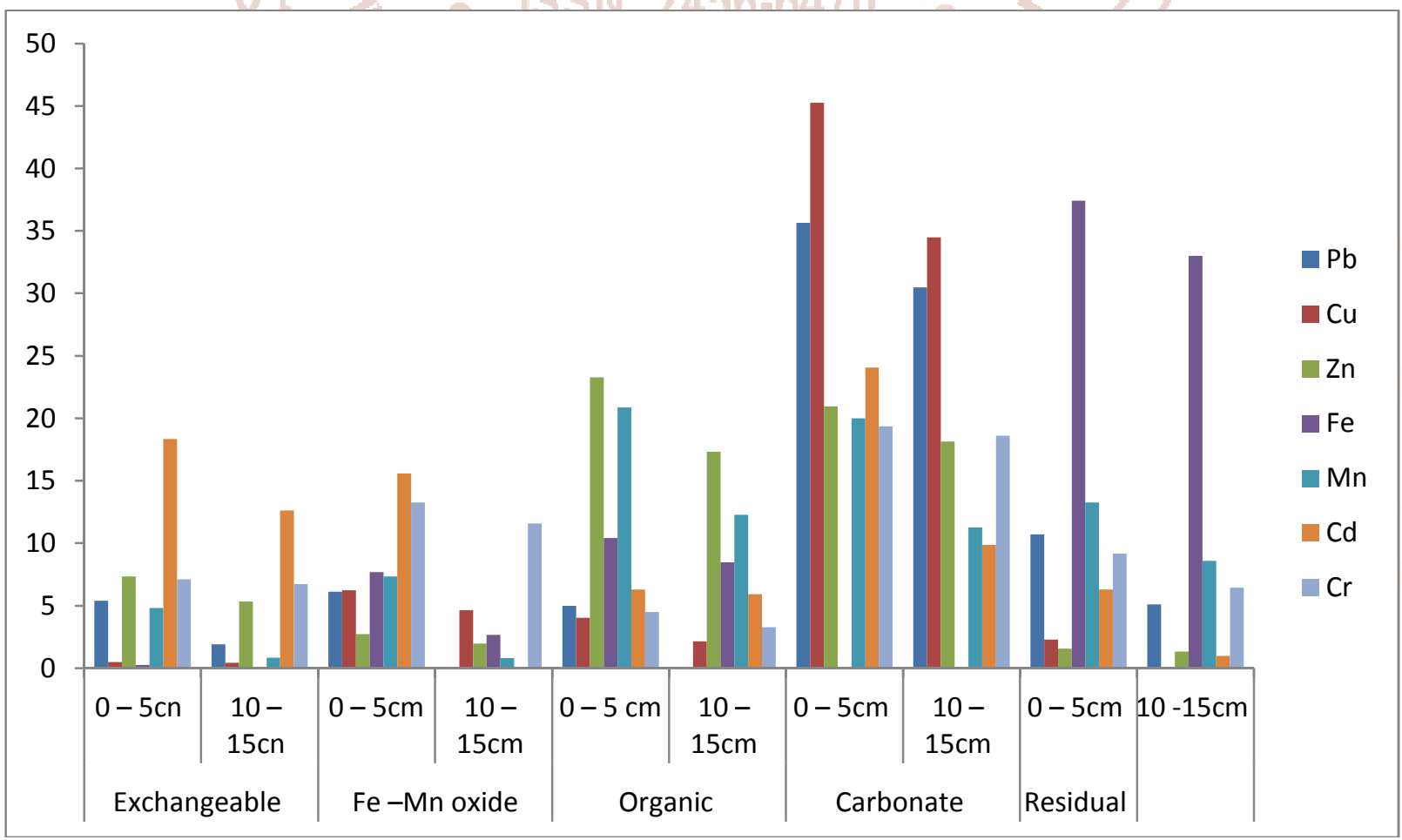

Figure2. Percentage concentration of metals from various fractions in dumpsite $A$ 


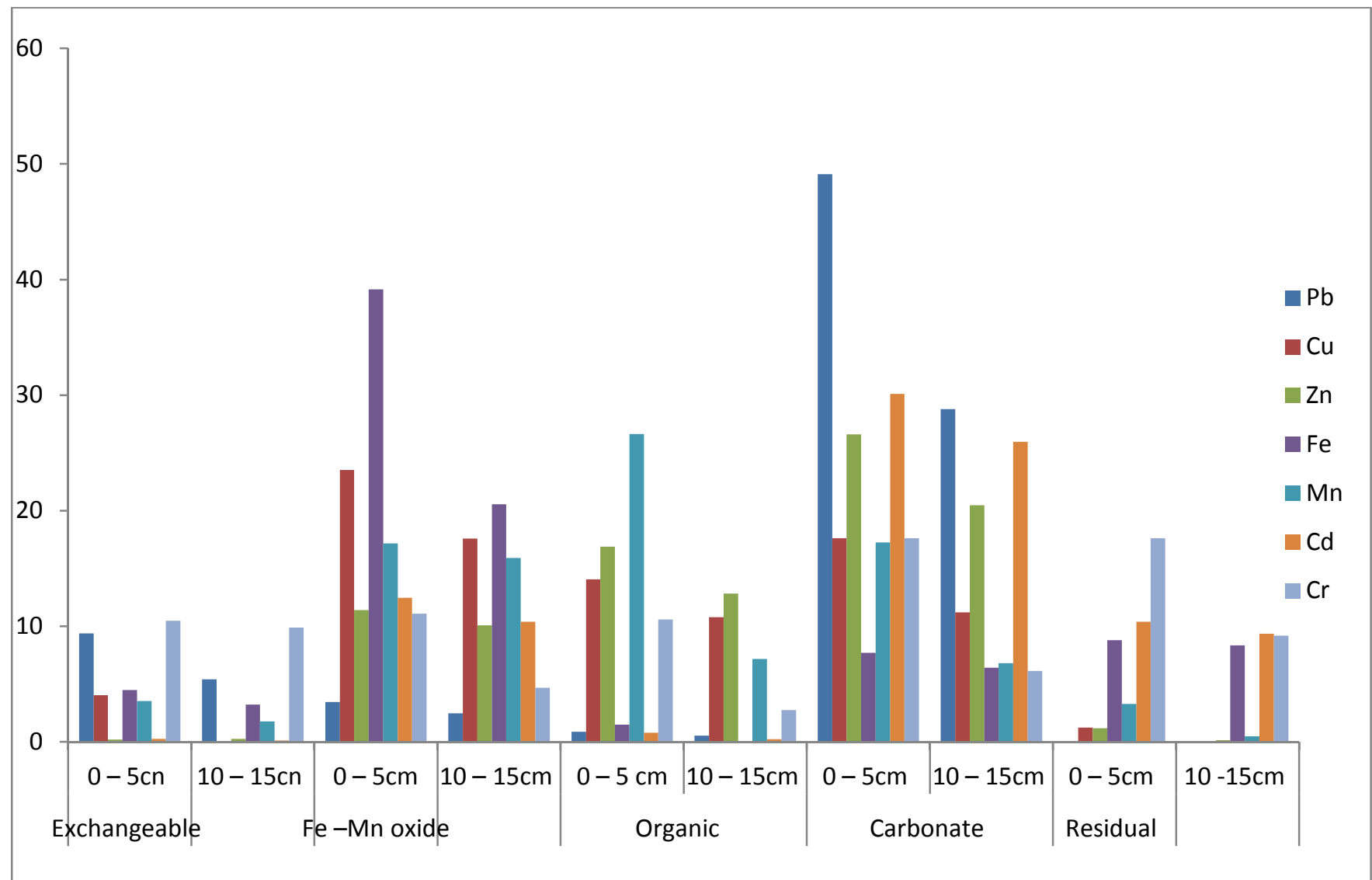

Figure 3Percentage concentrations of metals in the control dumpsite A

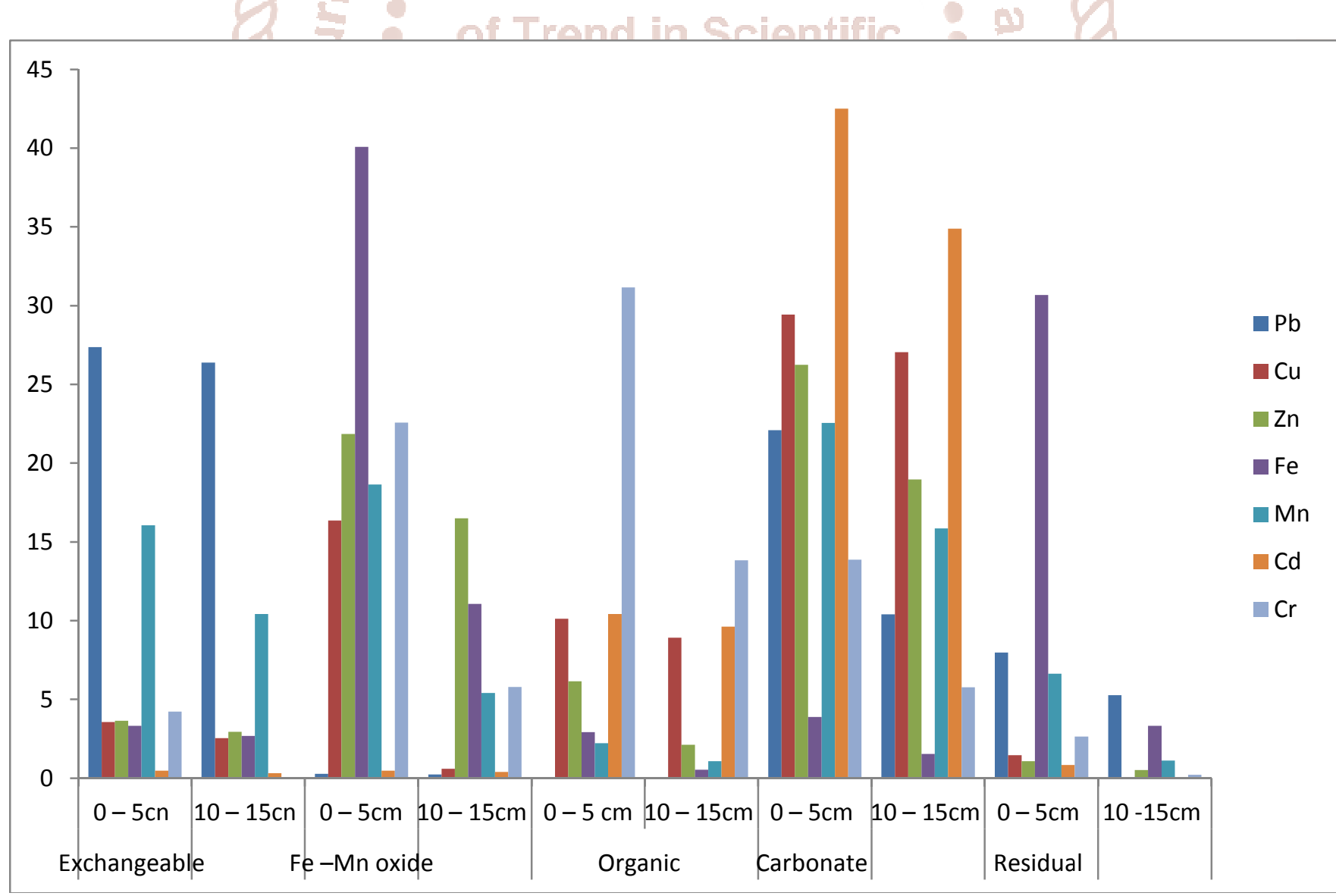

Figure 4percentage concentrations of various fractions in dumpsite $B$ 


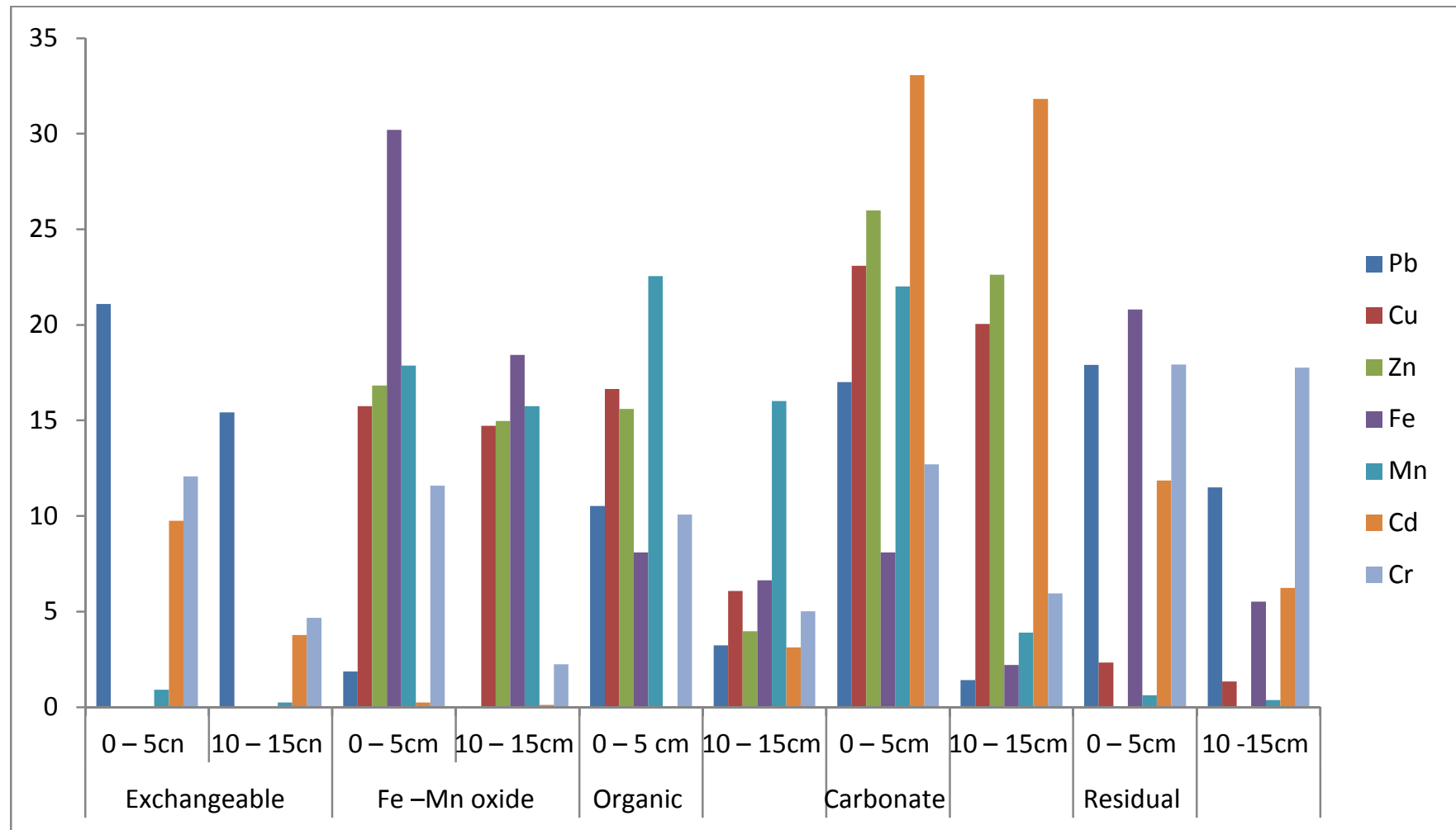

Figure 5 Percentage concentrations of various fractions in control dumpsite $B$

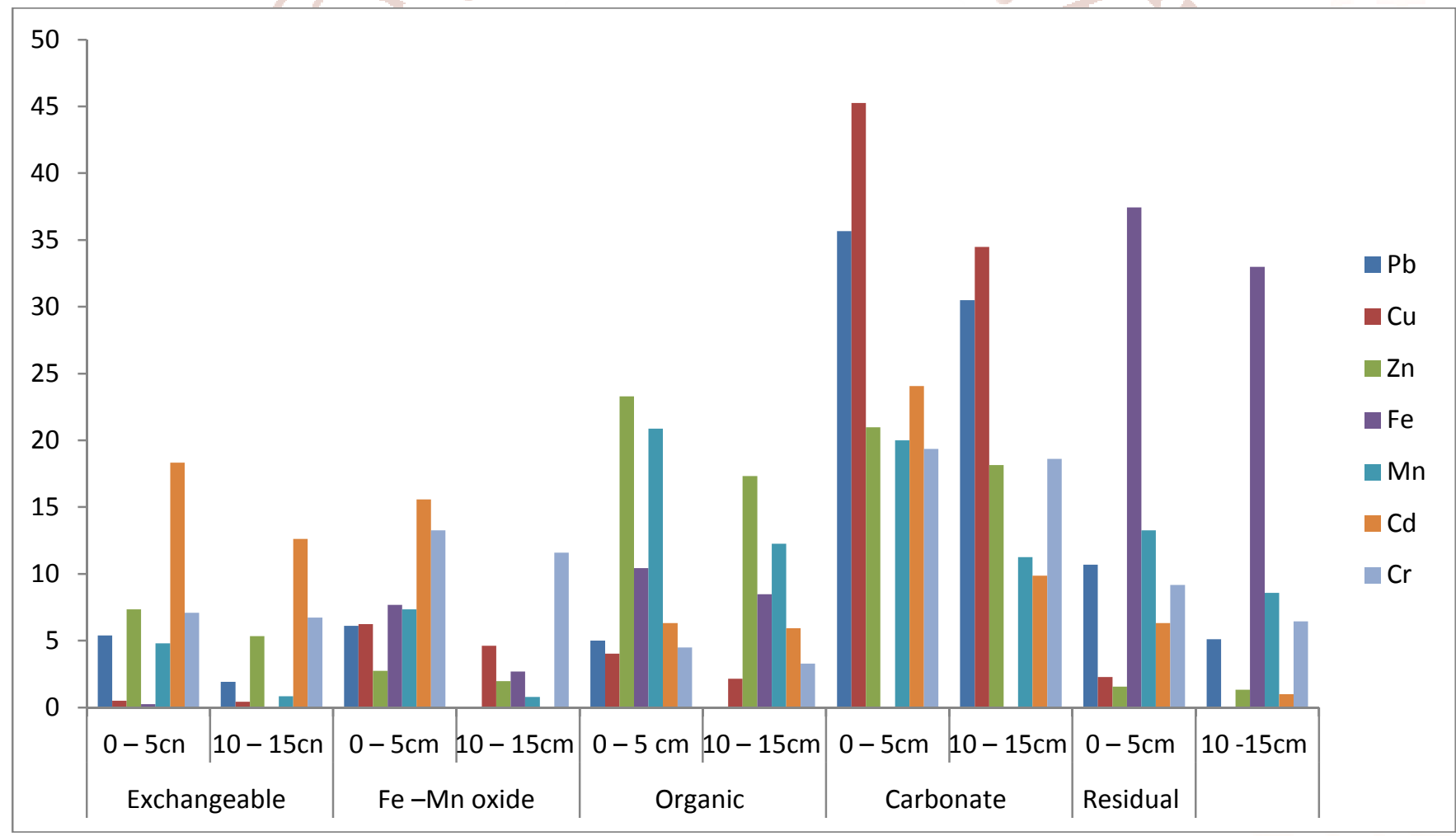

Figure 6 Percentage concentrations of metals in various fractions in dumpsite $\mathrm{C}$

Among the selected trace metals studied $(\mathrm{Pb}, \mathrm{Cu}, \mathrm{Zn}$, $\mathrm{Fe}, \mathrm{Mn}, \mathrm{Cd}$, and $\mathrm{Cr}$ ), in the total metal concentration shown in Table 1, Mn has the highest concentration of $6.680 \mathrm{mg} / \mathrm{kg}$ in dumpsite $\mathrm{B}$, and this could be attributed to the nature of the waste deposited in this dumpsite since the control of the same dumpsite $B_{12}$ shown Mn could not be detected properly because the concentration at which they are found is below the instrument detection limit. Some of the metals such as $\mathrm{Pb}, \mathrm{Cu}, \mathrm{Zn}$ and $\mathrm{Fe}$ were both detected in the three dumpsite $(\mathrm{A}, \mathrm{B}, \mathrm{C})$ but where not detected in the control which suggests the waste dumped in this site 
might actually be the source of pollution. Apart from $\mathrm{Mn}, \mathrm{Zn}$ shows a concentration of $3.850 \mathrm{mg} / \mathrm{kg}$ in dumpsite $\mathrm{C}$ followed by dumpsite B with $3.20 \mathrm{mg} / \mathrm{kg}$ and least with dumpsite $\mathrm{A}$ with the concentration of $0.950 \mathrm{mg} / \mathrm{kg}$. Lead $(\mathrm{Pb})$ was also next to zinc with the concentration of $1.501 \mathrm{mg} / \mathrm{kg}$ in dumpsite $\mathrm{B}$, followed by Dumpsite A $(1.306 \mathrm{mg} / \mathrm{kg})$ and least in dumpsite $\mathrm{C}$ with the concentration of $0.650 \mathrm{mg} / \mathrm{kg}$, this could be attributed to combustion of fuel from vehicles since these dumpsites located by the road side. For the control, there is presence of $\mathrm{Cd}$ and $\mathrm{Cr}$ from both dumpsite $\mathrm{A}$ and $\mathrm{B}$ control, this could be attributed to deposition by air/wind. Mn was not detected in control B but present in dumpsite B, this suggests that the waste from this dumpsite releases Mn to the soil.

For the distribution of the metals in the various fractions the results showthe concentration decreases as the depth increases. For the exchangeable in dumpsite $\mathrm{A}$ as shown in figure 2 all the metals studied are available with $\mathrm{Cr}$ having the highest percentages $21.66 \%$ in $0-5 \mathrm{~cm}$ depth but not detected as the depth increase $(10-15 \mathrm{~cm})$. Lead $(\mathrm{Pb})$ is next with the percentage of $15.84 \%$ within the depth of $0-5 \mathrm{~cm}$ and decreases to $13.36 \%$ with the depth of $10-15 \mathrm{~cm}$. From figure 3 for the control, the metals studied were also detected but at low concentration compared to the main dumpsite where this research was carried out, this mean the dumpsites could possible serves as a reaction site for the magnification of these metals which lead to increase in their concentrations. This trend was also reported by Adekola et al, 2012, Fegbote and Olanipekun, 2010). Similarly, other work by Godwin Oladele et al, 2012 reported high concentration of metals such as $\mathrm{Pb}, \mathrm{Cu}, \mathrm{Zn}$ and $\mathrm{Fe}$ where this increasewas attributed to exhaust from motor vehicles. For dumpsite B as shown in figure 4 similar pattern as in A was observed.The availability and concentration of the various metals, the order of the concentration is as follows: $\mathrm{Pb}>\mathrm{Mn}>\mathrm{Zn}>\mathrm{Cr}>$ $\mathrm{Cu}>\mathrm{Cd}$ with lead $(\mathrm{Pb})$ having the highest concentration and least in cadmium $(\mathrm{Cd})$ but for the control of dumpsite $\mathrm{B} \mathrm{Cu}, \mathrm{Zn}$ and $\mathrm{Fe}$ were not detected.

For dumpsite $\mathrm{C}$ in figure $6, \mathrm{Zn}$ has the highest concentration followed by lead.From this results it shows that shallow rooted crops can easily pick up some of these metals and bioaccumulate in the crops since their root is mostly at the surface of soil.
For Fe - Mn oxide fraction, dumpsite A show the highest values of $\mathrm{Mn}$ and $\mathrm{Fe}$, this agreed with the work of Uba et al., 2008 who attributed higher values to the precipitating amorphous, hydrous oxides of manganese during the ageing of the dumpsites (Staelens et al., 2006). For the control $\mathrm{Zn}$ has the highest value followed by manganese, this result disagreed with the result of Olutona et al., 2012 who reported higher values of $\mathrm{Mn}$ associated with carbonate fraction. For dumpsite $\mathrm{C}$ the order of concentration is $\mathrm{Zn}>\mathrm{Pb}>\mathrm{Fe}>\mathrm{Mn}>\mathrm{Cu}>\mathrm{Cr}>\mathrm{Cd}$ which agreed with the work of Fagbote and Olanipekun (2010) who discovered $\mathrm{Zn}$ to be the highest in the $\mathrm{Fe}-\mathrm{Mn}$ oxide fraction.

For organic fraction dumpsite A showed the highest value of Iron (Fe) (29.18\%) followed by $\mathrm{Pb}, \mathrm{Cd}$ and $\mathrm{Zn} 17.32 \%$ and $19.91 \%$ but the control has $\mathrm{Zn}$ to be highest with the value of $16.89 \%$ followed by manganese. For dumpsite B lead was not detected in this fraction but chromium has the highest concentration of $31.15 \%$. For the control Mn $(22.55 \%)$ has the highest within $0-5 \mathrm{~cm}$ depth followed by $\mathrm{Cu}(16.65 \%)$, then $\mathrm{Zn}(15.60 \%)$ but least in iron with the concentration of $8.10 \%$ for the depth of $0-5 \mathrm{~cm}$ but for the depth of $10-15 \mathrm{~cm} \mathrm{Mn}(16.02 \%)$ is the highest and least with $\mathrm{Zn}(3.98 \%)$.

For dumpsite $\mathrm{C}$ the order is $\mathrm{Zn}>\mathrm{Mn}>\mathrm{Fe}>\mathrm{Pb}>\mathrm{Cu}$ $>\mathrm{Cr}>\mathrm{Cd}$ other researchers reported same pattern (Fagbote and Olanipekun, 2010).

This work also shows that in the carbonate fraction the dumpsite $\mathrm{A}$ is in the order of $\mathrm{Pb}>\mathrm{Cd}>\mathrm{Zn}>\mathrm{Cu}>$ $\mathrm{Cr}>\mathrm{Mn}>\mathrm{Fe}$, for the dumpsite $\mathrm{A}$ control is in the order of $\mathrm{Zn}>\mathrm{Pb}>\mathrm{Mn}>\mathrm{Fe}>\mathrm{Cr}>\mathrm{Cu}>\mathrm{Cd}>\mathrm{Fe}$. For dumpsite $\mathrm{B}$ the order is $\mathrm{Mn}>\mathrm{Zn}>\mathrm{Cd}>\mathrm{Cu}>\mathrm{Pb}>\mathrm{Cr}$ $>\mathrm{Fe}$. In the case of dumpsite $\mathrm{C}$ the order is $\mathrm{Zn}>\mathrm{Pb}>$ $\mathrm{Cu}>\mathrm{Cr}>\mathrm{Cd}>\mathrm{Fe}$. Chromium and Iron have a very low value in this fraction. The concentration of iron in this fraction agreed with the work reported by Abdulsalam et al., (2011) which showed relatively low amount of iron in the carbonate fraction. Fagbote and olanipekun 2010 also reported similar lower amount of iron associated with this fraction.

The last of the fraction which is Residual fraction, most of the metal studied were found and for dumpsiteA the order are $\mathrm{Mn}>\mathrm{Pb}>\mathrm{Cd}>\mathrm{Cr}>\mathrm{Zn}>\mathrm{Cu}$ $>\mathrm{Fe}$.For the control $\mathrm{Pb}$ was not detected and the order of the distribution is $\mathrm{Cr}>\mathrm{Mn}>\mathrm{Cd}>\mathrm{Zn}>\mathrm{Fe}>\mathrm{Cu}$. For dumpsite $\mathrm{B}$ all the metals studied are available 
with cadmium having the least concentration of $0.99 \%$ but $\mathrm{Zn}$ was not detected for dumpsite $\mathrm{C}$ iron has the highest concentration while the order of availability is $\mathrm{Fe}>\mathrm{Pb}>\mathrm{Mn}>\mathrm{Zn}>\mathrm{Cr}>\mathrm{Cu}>\mathrm{Cd}$. Researchers like Effiong and Gilbert 2012 reported similar trend in their work and Wufem et al., 2009 reported same trend in their work with iron having the highest concentration.

In conclusion the primary objective of this study was to determines the mobility and availability of selected trace metals in soil from dumpsite, all the metals studied are available and theirconcentration decreases as the depth increases and the concentration of these metals are higher in the dumpsite than the control which shows that dumpsite contribute greatly in releasing of metals to the soil.

\section{References}

1. Abdul;-salam, N, Ibrahim, M.S and Fatoyinbo F.T (2011) Dumpsite in Lokoja, Nigeria. A silent pollution Zone for underground water. Journal of Waste Management and Bioresources Tech. pp 21 -30 .

2. Adelekan B.A., Abegude, K.D (2011) Heavy metals contamination of soil and good water at automobile mechanic villages in Ibadan. Nigeria, International Journal of Physical Sciences 6 (5) $1045-1058$.

3. Alloway, B.J (1995) Heavy metals in soil John Willey \& Sons new York.

4. Effiong, U, Etirn and Gubert, U. Adie (2012) Assessment of toxic heavy metal leaching in top soil samples within the vicinity of a limestone's quany in South Western Nigeria. African Journal of Environmental Science and Techn. Vol. 6(8) pp $322-330$

5. Fagbote, E.O and Olanipekun, O.E (2010) Evaluation of the status of heavy metals pollution of soil and plant (chromokenaodwata) of Agbabubitmendposit Area, Nigeria publisher by America Eurasian Journal of Scientific Research 5(4) $241-248$.

6. Godwin O.O, Olapeju, G.A and Emmanuel A.A (2012) A study of chemical speciation of metals in aquatic bottom sediments of Aiba reservoir, Iwo, Nigeria, African Journal of Environmental Science and Tech. Vol. 16(8) 312 - 321.

7. Ibrahim E.G, Egila, J.N and Gube - Ibrahim, M.A (2013) speciation of some selected trace metals in soil samples from dumpsite in Lafia, Nasarawa State. Nigeria Journal of Multidisciplinary Research Volume 5(2) 63 - 73.

8. Maina, H.M, Egila, J.N and Shagai, M.H (2012), Chemical Speciation of Some Heavy Metals in Sediment in the Vicinity of Ashaka Cement Factory Gombe State, Nigeria. Journal of Research in Environ. Science and Tech. Vol. 1(7) pp186

9. Mansouri, B, Baramaki, R, and Ebrahim Pour, M (2012) acute toxicity bioassay of mercury and silver on capeotajusca (black fish) journal of toxicology and industrial health 28 (5) $393-398$.

10. Olutona, G.O, Olapeju, G.A and Emmanuel, A.A (2012). A study of chemical speciation of metals in aquatic bottom sedminent of Aiba reservoir Iwo Nigeria. African Journal of Environmental Science and Techn. Vol. 1. 6(8) 312 - 321.

11. Salati, S and Moore, F (2010) Assessment of heavy metal concentration in the Khoshik River water and sediment shiraz south west Iran. Environmental monitoring and assessment 164 (1) $677-689$.

12. Sanchez IJ. Manino, N, Vanquero, M.C, Ansorena, J and LEgoiuru (2007) Metal pollution by old lead - zinc mines in Urumea River Valley (Basque count Spain) soil, birta and sediment water, air and soil pollution 107 (1) 303 - 319.

13. Tessier, A. Campbell, P.G.C and Blsson, $M$ (1979) sequential extraction procedure for the speciation of particulate trace metals. Analytical Chemistry 52 (1) $45-53$.

14. Uba, S. Uzariu, A, Hanson, G. F. S and Balarabe, M.L (2008) Assessment of heavy metals bioavailability in Dumpsite of Zaria metropolis Nigeria. African Journal of Biotechnology Vol 7 (2) $120-130$.

15. Wufem, B.M, Ibrahim, A.Q. Gim, NS, Mohammed M.AEkanem E.O and Shibdawa, M.A (2007) speciation of heavy metals in the sediments of Gubi dam Bauchi state, Nigeria Global Journal of Environmental Science 8(2) 55 - 63

16. Yashim, Z.I, Agbaji, E.B, Gimba, C.E and Idris, S. O (2016) mobility and bioavailability of some heavy metals in soil from selected metals dumpsites in Zaria, Nigeria. Book of proceeding of the $12^{\text {th }}$ chem Class Conferenc CSN ABU Chapter. 